\title{
Learner Attitude towards Chemistry, Study Skills and Examination Preparedness: A Case of a Public School in Eastern, Kenya
}

\author{
Winnie Muthoni Ngila, Lazarus Ndiku Makewa* \\ University of Eastern Africa, Baraton \\ *Corresponding author: ndikul@gmail.com
}

Received September 23, 2014; Revised October 09, 2014; Accepted December 08, 2014

\begin{abstract}
This study intended to test if there was significant difference in chemistry preparedness in terms of attitude towards chemistry, study skills and exam preparedness between boys and girls, between boarders and day scholars and between low and high achievers. Two hundred and eleven (211) subjects participated. A questionnaire was designed to measure preparedness in chemistry in relation to attitude towards chemistry, study skills, and exam preparedness. To address the hypotheses, frequency distributions and other descriptive statistics including means, standard deviations and percentages were used. Independent sample t-tests were performed to address the first and the second hypotheses to determine whether differences between variables existed. The results indicate that there is homogeneity of variance amongst attitude towards chemistry, study skills and exam preparedness. The findings also inform that preparedness in chemistry in terms of attitude towards chemistry, study skills, and exam preparedness is the same in both boys and girls but boys lagged slightly below girls in attitude towards chemistry. There was no significant difference in chemistry preparedness between genders in relation to these variables. Borders and day scholars have similar preparedness in chemistry in terms of attitude, study skills and exam preparedness. The results further show that day scholars have a slightly higher preparedness in chemistry than the boarders. Higher achievers have more positive attitude towards chemistry, better study skills and higher exam preparedness.
\end{abstract}

Keywords: learner, attitude, chemistry, study skills, examination preparedness

Cite This Article: Winnie Muthoni Ngila, and Lazarus Ndiku Makewa, "Learner Attitude towards Chemistry, Study Skills and Examination Preparedness: A Case of a Public School in Eastern, Kenya.” American Journal of Educational Research, vol. 2, no. 11A (2014): 8-15. doi: 10.12691/education-2-11A-2.

\section{Introduction}

Attitudes, as constructs of affective domain, have been in the research forum for several years (Aiken \& Aiken, 1969; Koballa \& Crawley, 1985; Koballa, 1988). Attitudes have determined the power to predict future behaviors like subject and career preferences of learners (Koballa, 1988; Osborne, Simon \& Collins, 2003), and the relationship existing between attitude and academic achievement (Schibeci, 1984; Shrigley, 1990; Weinburgh, 1995; Osborne \& Collins, 2000). In their meta-analysis of attitude related factors that predict future behaviors, Glasman and Albarracín (2006) concluded that there is a correlation between attitudes and future behaviors; that is, attitudes are a potential for predicting future preferences, especially if there is a direct interaction between participants and the attitude object (i.e. objects that related to attitude like science lessons). Actually, studies that examined the correlation between attitude and academic achievement did not provide consistent results. Schibeci (1984), for instance, found a strong relationship between attitude and achievement. Shrigley (1990), on the other hand, argued that there is only moderate relationship between attitudes toward science and science achievement. Add some more studies please.

The attitude literature has concentrated on a range of aspects (Osborne et al., 2003) such as defining attitude and making a distinction among similar terms (Koballa, 1988), defining attitude objects (Spall, Dickson \& Boyes, 2004), and developing attitude constructs (Kind, Jones \& Barmby, 2007).

Besides defining attitudes and dimensions of attitude, the literature deals widely with the factors affecting attitude toward science. Grade levels (Hofstein, Ben-Zvi, Samuel \& Tamir, 1977; Yager \& Yager, 1985; Simpson \& Oliver, 1990; Francis \& Greer, 1999; George, 2006; Barmby et al., 2008), gender (Hofstein et al., 1977; Harvey \& Stables, 1986; Francis \& Greer, 1999; Barmby et al., 2008), achievement (Weinburgh, 1995; Salta \& Tzougraki, 2004) are some of the most investigated factors affecting secondary school students' attitudes toward science.

Study skills are those skills which are required for understanding and retrieving information; particular they are the link between comprehension and memorization (Al- Hilawani \& Sartawi, 1997). Hoover (1989) has listed specific competencies of study skills including acquiring information, recording information, recording appropriate 
responses to the presented information, locating the required information, organizing and managing activities efficiently, synthesizing information to create meaningful patterns of responses, and memorizing and retrieving information on demand.

Literature boasts of studies suggesting benefits of utilizing effective study skills. Al-Hilawani and Sartawi (1997) report students with improved GPA had adequate study skills, and students who are academically unsuccessful, sparingly use study skills than high achieving students. Hoover (1989) indicates that good study skills and habits are the tools that assist students during the learning process in order to acquire and retain new information and are essential for students' successful academic performance. Jones, Slate and Kyle (1992) reported that high achieving students have better study skills than low achieving students in areas of time management, study techniques and attitudes toward learning.

DiVesta and Moreno (1993) viewed study skills as a compensation for cognitive limitations in the information processing system and reported that there was a significant correlation between GPA and comprehension monitoring activities, which in turn was an indication that students with high GPA practice self awareness, purposeful planning and self-adjustment activities more than students with low GPA. Studies self-regulated learning examines this process in terms of teachable cognitive skills where students learn to think about the way they learn (Paris \& Winograd, 2001).

While positive study behaviors are important to student achievement, knowledge of the actual study behaviors and techniques utilized is rather limited (Elliot et al, 2002). Scholars do however agree that students typically utilize a variety of studying techniques (Allgood et al, 2000), while the actual techniques utilized are rarely documented (King 1992; Stanley et al., 1999; Van Meter et al, 1994; Wood et al. 1999).

Self-regulated learners' proactive qualities and selfmotivating abilities help to distinguish them from their peers. Research shows that self-regulated students are more engaged in their learning. These learners commonly seat themselves toward the front of the classroom (Labuhn, Zimmerman, \& Hasselhorn, 2010), voluntarily offer answers to questions (Elstad \& Turmo, 2010), and seek out additional resources when needed to master content (Clarebout, Horz, \& Schnotz, 2010). Most importantly, self-regulated learners also manipulate their learning environments to meet their needs (Kolovelonis, Goudas, \& Dermitzaki, 2011).

For example, researchers have found that self-regulated learners are more likely to seek out advice (Clarebout et al., 2010) and information (De Bruin et al., 2011) and pursue positive learning climates (Labuhn et al., 2010), than their peers who display less self-regulation in the classroom. Due to their resourcefulness and engagement, it is not then surprising that findings from recent studies suggest that self-regulated learners also perform better on academic tests and measures of student performance and achievement (Schunk \& Zimmerman, 2007; Zimmerman, 2008).

To promote SRL in classrooms, teachers must teach students the self-regulated processes that facilitate learning. These processes often include: goal setting
(Winne \& Hadwin, 1998; Wolters, 1998), planning (Zimmerman, 2004; Zimmerman \& Risemberg, 1997), self-motivation (Corno, 1993; Wolters, 2003; Zimmerman, 2004), attention control (Harnishferger, 1995; Kuhl, 1985; Winne, 1995), flexible use of learning strategies (van de Broek, Lorch, Linderholm, \& Gustafson, 2001; Winne, 1995), self-monitoring (Butler \& Winne, 1995; Carver \& Scheier, 1990), appropriate help-seeking (Butler, 1998; Ryan, Pintrich, \& Midgley, 2001), and self-evaluation (Schraw \& Moshman, 1995).

Creating SRL environments for the complex and diverse range of backgrounds, skill sets, and personalities that many students encompass poses challenges to the most experienced teachers too. Fortunately, a great deal of literature showcases a variety of effective instructional strategies for encouraging self-regulation in the classroom (Andreassen \& Braten, 2011; Boekaerts \& Corno, 2005; Cleary \& Zimmerman, 2004; De Corte, Mason, Depaepe, \& Verschaffel, 2011; Dignath \& Buettner, 2008; Graham, Harris \& Mason, 2004; Souvignier \& Mokhlesgerami, 2006; Stoeger \& Ziegler, 2011; Tonks \& Taboada, 2011). Some of these strategies include direct instruction and modeling, guided and independent practice, social support and feedback, and reflective practice.

\section{Method}

This study tested three null hypotheses:

a. HO: There is no significant difference in chemistry preparedness in terms of attitude towards chemistry, study skills and exam preparedness between boys and girls.

b. HO: There is no significant difference in chemistry preparedness in terms of attitude towards chemistry, study skills and exam preparedness between boarders and day scholars.

c. HO: There is no significant difference in chemistry preparedness in terms of attitude towards chemistry, study skills and exam preparedness between low and high achievers.

\subsection{The Sample}

The respondents were secondary school students from all classes (form 1 to form 4) from a public school in Kenya whose student population is 689 students. Since the sample was obtained from already existing groups, the sampling design qualified to be stratified sampling. Through purposive sampling, it was ensured that the strata (all classes) were adequately represented in the sample. The valid sample size was composed of 211 subjects of which 111 were boys and 100 were girls. Of all the respondents in the sample, 56 were in form one, 51 in form two, 54 in form three and 50 in form four. Majority (173 students) aged between 15 and 18 years and few aged below 15 (14 students) and above 18 (24 students) years.

\subsection{The Instrument}

For the purpose of this survey, a questionnaire was designed to measure preparedness in chemistry in relation to attitude towards chemistry, study skills, and exam preparedness. The first part of the questionnaire was designed to get demographic information from the students. This part of the questionnaire garnered students' 
information on gender, being a boarder or a day-scholar and students' score in the previous term's chemistry exam. The second part of the questionnaire consisted of 12 items to assess students' attitude towards chemistry, 19 items to dig up information on study skills, and 12 items to assess exam preparedness.

Each respondent was instructed to read the statements in part one and put a tick in the brackets against the most appropriate answer to the question asked. In a four likert scale; 1- Disagree, 2- Tend to Disagree, 3- Tend to Agree, and 4- Agree, the respondents were asked to put a tick in the box matching best matching his/her opinion in the four columns.

The total number of items used in the questionnaire was 47 and were in two categories, 30 positively stated statements and 17 negatively stated statements, all used to draw information from the respondents. The negatively stated statements were recorded, hence, given values 4,3 , 2 , and 1 instead of $1,2,3$ and 4 before performing treatments with SPSS apart from obtaining the frequency tables.

Using the 47 items, the questionnaire's reliability was found to be .901 with a Cronbach's test against an alpha value of .05, implying that the probability of not committing type 1 error was 95 per cent.

\subsection{Data Analysis}

All analyses were performed using the Statistical Package for Social Science (SPSS). To address the hypotheses, frequency distributions and other descriptive statistics including means, standard deviations and percentages were used. Descriptive statistics describe basic feature of the data under study in simple summaries (Vogt et al., 2014). Independent sample t-tests were performed to data used to address the first and the second hypotheses because there was need to determine whether differences between variables existed. Independent sample t-test compares means' differences between two independent samples (Bui, 2009). For the third hypothesis, Pearson product Moment Correlation Coefficients was determined to test relationships between variables.

\section{Results and Discussion}

HO: There is no significant difference in chemistry preparedness in terms of attitude towards chemistry, study skills and exam preparedness between boys and girls.

To test the attitude towards chemistry, study skills and exam preparedness as aspects of 'preparedness in chemistry', students responded to statements in a likert scale format which had a 4-point rating scale labeled; 1 disagree, 2-tend to disagree, 3-tend to agree and 4-agree. Independent samples t-test was done to determine whether there is a significant difference between boys' and girls' preparedness in chemistry in relation to attitude towards chemistry, study skills, and exam preparedness. The results were as shown in Table 1 and Table 2 and summarized in Table 3.

Table 1.

\begin{tabular}{|c|c|c|c|c|c|}
\hline \multicolumn{9}{c|}{ Group Statistics } \\
\hline & Gender & $\mathrm{N}$ & Mean & Std. Deviation & Std. Error Mean \\
\hline \multirow{2}{*}{ ATTITUDE TOWARDS CHEMISTRY } & Male & 111 & 3.5627 & .50930 & .04834 \\
\cline { 2 - 6 } & Female & 100 & 3.5893 & .46577 & .04658 \\
\hline \multirow{2}{*}{ STUDYSKILLS } & Male & 111 & 3.1396 & .46378 & .04402 \\
\cline { 2 - 6 } & Female & 100 & 3.1144 & .44541 & .04454 \\
\hline \multirow{2}{*}{ EXAM PREPAREDNESS } & Male & 111 & 3.4392 & .55595 & .05277 \\
\cline { 2 - 6 } & Female & 100 & 3.3991 & .54647 & .05465 \\
\hline
\end{tabular}

Table 2.

\begin{tabular}{|c|c|c|c|c|c|c|c|c|c|c|}
\hline \multicolumn{11}{|c|}{ Independent Samples Test } \\
\hline & & \multicolumn{2}{|c|}{$\begin{array}{c}\text { Levene's Test for } \\
\text { Equality of } \\
\text { Variances }\end{array}$} & \multicolumn{7}{|c|}{ t-test for Equality of Means } \\
\hline & & \multirow[b]{2}{*}{$\mathrm{F}$} & \multirow[b]{2}{*}{ Sig. } & \multirow[b]{2}{*}{$\mathrm{t}$} & \multirow[b]{2}{*}{ df } & \multirow[b]{2}{*}{$\begin{array}{l}\text { Sig. (2- } \\
\text { tailed) }\end{array}$} & \multirow[b]{2}{*}{$\begin{array}{c}\text { Mean } \\
\text { Difference }\end{array}$} & \multirow[b]{2}{*}{$\begin{array}{l}\text { Std. Error } \\
\text { Difference }\end{array}$} & \multicolumn{2}{|c|}{$\begin{array}{l}\text { 95\% Confidence } \\
\text { Interval of the } \\
\text { Difference }\end{array}$} \\
\hline & & & & & & & & & Lower & Upper \\
\hline \multirow{2}{*}{$\begin{array}{l}\text { Attitude Towards } \\
\text { Chemistry }\end{array}$} & $\begin{array}{c}\text { Equal } \\
\text { variances } \\
\text { assumed }\end{array}$ & 1.079 & .300 & $\begin{array}{c}- \\
.395\end{array}$ & 209 & .694 & -.02661 & .06744 & -.15957 & .10634 \\
\hline & $\begin{array}{c}\text { Equal } \\
\text { variances not } \\
\text { assumed }\end{array}$ & & & $\begin{array}{c}- \\
.396\end{array}$ & 208.950 & .692 & -.02661 & .06713 & -.15895 & .10572 \\
\hline \multirow{2}{*}{ Study Skills } & $\begin{array}{c}\text { Equal } \\
\text { variances } \\
\text { assumed }\end{array}$ & .285 & .594 & .400 & 209 & .689 & .02512 & .06276 & -.09860 & 14883 \\
\hline & $\begin{array}{c}\text { Equal } \\
\text { variances not } \\
\text { assumed }\end{array}$ & & & .401 & 208.135 & .689 & .02512 & .06262 & -.09834 & .14857 \\
\hline \multirow{2}{*}{$\begin{array}{c}\text { Exam } \\
\text { Preparedness }\end{array}$} & $\begin{array}{c}\text { Equal } \\
\text { variances } \\
\text { assumed }\end{array}$ & .297 & .586 & .527 & 209 & .598 & .04010 & .07603 & -.10979 & .18999 \\
\hline & $\begin{array}{c}\text { Equal } \\
\text { variances not } \\
\text { assumed }\end{array}$ & & & .528 & 207.404 & .598 & .04010 & .07597 & -.10967 & .18986 \\
\hline
\end{tabular}


Table 3.

\begin{tabular}{|c|c|c|c|c|c|c|}
\hline & & Male & & Female & & \\
\hline & Mean & Standard Deviation & Mean & Standard Deviation & $t(d f)$ & Sig \\
\hline Attitude towards chemistry & 3.5627 & .50930 & 3.5893 & .46577 & $.395(209)$ & .694 \\
\hline Study skills & 3.1396 & .46378 & 3.1144 & .44541 & $.400(209)$ & .689 \\
\hline Exam preparation & 3.4392 & .55595 & 3.3991 & .54647 & .527(209) & .598 \\
\hline
\end{tabular}

In Table 2, the Levene's test for equality of variances has Sig values of .300 for 'attitude towards chemistry', .594 for 'study skills' and .586 for 'exam preparedness' which are greater than .05 (alpha value). The null hypotheses for testing for homogeneity, 'there is homogeneity of variance' are therefore accepted. This confirms that sample groups were obtained from populations which have equal variances (Quinn \& Keogh, 2002).

Table 3 above shows that the p-values for the three aspects of chemistry preparedness are above the alpha value which is $.05(\mathrm{P}=.694, \mathrm{P}=.689, \mathrm{P}=.598)$, meaning the null hypothesis 'there is no significant difference in chemistry preparedness in terms of attitude towards chemistry, study skills and exam preparedness between boys and girls' is accepted. In other words, boys' preparedness in chemistry in terms of attitude towards chemistry, study skills, and exam preparedness is the same as that of girls. The mean for the attitude towards chemistry is slightly higher in girls than in boys. But this difference is not statistically significant.

The findings are in harmony with those of Satta and Tzouglaki (2004) whose study found no differences between boys' and girls' attitude towards chemistry, but differs in the sense Satta and Tzouglaki (2004) observed a tendency of girls to be more negative than boys.

The findings contradict those of many studies done in the recent past (Nyamba \& Mwajombe, 2012; Can, 2012; Cheung, 2007). Although many studies agree that gender is a factor that influences attitude towards chemistry (Nyamba and Mwajombe 2012; Can, 2012; Cheung, 2012), their findings vary in that some studies find girls to have a more positive attitude (Cheung 2007). Other studies find girls to lag slightly behind boys in attitude towards chemistry (Nyamba \& Mwajombe, 2012) but this survey found out that boys lag slightly below girls in attitude towards chemistry. Cheung (2007) in a study on the interactive effect between grade level and gender discovered that males reported greater liking for chemistry theory lessons than their female counterparts. In a study on Gender Disparities in Self-concept, Attitude and Perception in Physics and Chemistry, male students had a more positive attitude towards Physics than the female students though the differences were not statistically significant and mean attitude scores of both groups show that these students had positive attitude toward Physics and Chemistry (Inzahuli, Role \& Makewa, 2012).

Table 4.

\begin{tabular}{|c|c|c|c|c|c|}
\hline \multicolumn{6}{|c|}{ Group Statistics } \\
\hline & Residence & $\mathrm{N}$ & Mean & Std. Deviation & Std. Error Mean \\
\hline \multirow{2}{*}{ Attitude towards Chemistry } & Day scholar & 140 & 3.5855 & .46190 & .03904 \\
\hline & Boarder & 71 & 3.5554 & .53916 & .06399 \\
\hline \multirow{2}{*}{ Study Skills } & Day scholar & 140 & 3.1307 & .46227 & .03907 \\
\hline & Boarder & 71 & 3.1216 & .44121 & .05236 \\
\hline \multirow{2}{*}{ Exam Preparedness } & Day scholar & 140 & 3.4160 & .56967 & .04815 \\
\hline & Boarder & 71 & 3.4284 & .51453 & .06106 \\
\hline
\end{tabular}

Table 5.

\begin{tabular}{|c|c|c|c|c|c|c|c|c|c|c|}
\hline \multicolumn{11}{|c|}{ Independent Samples Test } \\
\hline & & \multicolumn{2}{|c|}{$\begin{array}{c}\text { Levene's Test for } \\
\text { Equality of } \\
\text { Variances }\end{array}$} & \multicolumn{7}{|c|}{ t-test for Equality of Means } \\
\hline & & \multirow[b]{2}{*}{$\mathrm{F}$} & \multirow[b]{2}{*}{ Sig. } & \multirow[b]{2}{*}{$\mathrm{T}$} & \multirow[b]{2}{*}{ df } & \multirow[b]{2}{*}{$\begin{array}{l}\text { Sig. (2- } \\
\text { tailed) }\end{array}$} & \multirow[b]{2}{*}{$\begin{array}{c}\text { Mean } \\
\text { Difference }\end{array}$} & \multirow[b]{2}{*}{$\begin{array}{l}\text { Std. Error } \\
\text { Difference }\end{array}$} & \multicolumn{2}{|c|}{$\begin{array}{l}\text { 95\% Confidence } \\
\text { Interval of the } \\
\text { Difference }\end{array}$} \\
\hline & & & & & & & & & Lower & Upper \\
\hline \multirow{2}{*}{$\begin{array}{l}\text { Attitude Towards } \\
\text { Chemistry }\end{array}$} & $\begin{array}{c}\text { Equal } \\
\text { variances } \\
\text { assumed }\end{array}$ & .134 & .715 & .422 & 209 & .673 & .03008 & .07127 & -.11041 & .17057 \\
\hline & $\begin{array}{c}\text { Equal } \\
\text { variances not } \\
\text { assumed } \\
\end{array}$ & & & .401 & 123.210 & 689 & .03008 & .07495 & -.11829 & .17844 \\
\hline \multirow{2}{*}{ Study Skills } & $\begin{array}{c}\text { Equal } \\
\text { variances } \\
\text { assumed } \\
\end{array}$ & .092 & .762 & .138 & 209 & .890 & .00917 & .06634 & -.12161 & 13995 \\
\hline & $\begin{array}{c}\text { Equal } \\
\text { variances not } \\
\text { assumed }\end{array}$ & & & .140 & 146.734 & .889 & .00917 & .06533 & -.11994 & .13828 \\
\hline \multirow{2}{*}{$\begin{array}{c}\text { Exam } \\
\text { Preparedness }\end{array}$} & $\begin{array}{c}\text { Equal } \\
\text { variances } \\
\text { assumed } \\
\end{array}$ & .001 & .970 & $\begin{array}{c}- \\
.154\end{array}$ & 209 & .878 & -.01239 & .08040 & -.17088 & .14611 \\
\hline & $\begin{array}{c}\text { Equal } \\
\text { variances not } \\
\text { assumed }\end{array}$ & & & $\begin{array}{c}- \\
.159\end{array}$ & 154.095 & .874 & -.01239 & .07776 & -.16600 & .14123 \\
\hline
\end{tabular}

Can (2012) did a similar study to that of Cheung (2007), but realized that female students expressed a higher liking

for chemistry lessons than male students. In both cases, these studies had similar findings, that both boys' and 
girls' attitude towards chemistry is slightly average, this survey's finding concurs with their findings. The trend in attitude towards chemistry in relation to gender varies with factors that can be determined in another study.

Similarly, the $p$ values for the study skills $(p=.689)$ and exam preparedness $(p=.598)$ were average and above, indicating that, there is no significance in chemistry preparedness between genders in relation to these variables.
HO: There is no significant difference in chemistry preparedness in terms of attitude towards chemistry, study skills and exam preparedness between boarders and day scholars. The results for the independent t-test are in the Table 4 and Table 5 and summarized in Table 6.

The Levenes sig values as indicated in Table 5 are .715 for 'attitude towards chemistry', .762 for 'study skills', and .970 'for exam preparedness' all of which are greater than the critical value of .05 . The implication is that there is homogeneity of variance.

Table 6.

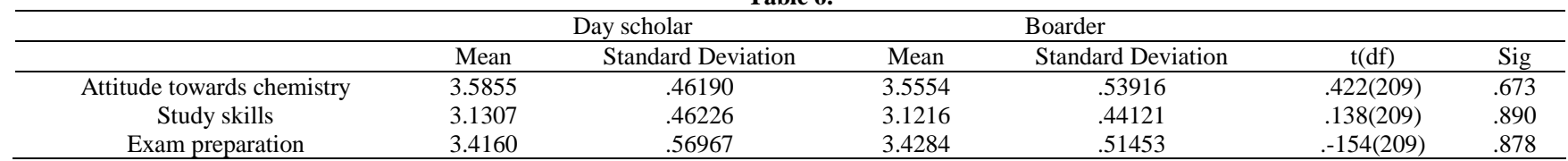

In Table 6 , all the $\mathrm{p}$-values $(\mathrm{P}=.673, \mathrm{P}=890, \mathrm{P}=878)$ are greater than .05 hence the null hypothesis is accepted. Borders and day scholars have similar preparedness in chemistry in terms of attitude, study skills and exam preparedness. However, the day scholars have a slightly higher preparedness in chemistry $(\mu=3.5855)$ than the boarders $(\mu=3.5554)$. Previously in this study, it has been revealed that the students have a notable problem with consulting their teachers. While the boarders spend most of their time with the teachers and other supportive staff, they may lack as much encouragement at school as the day-scholars get from home. As Azubuike (2011) found out in a study on factors that influence attitude towards vocational subjects, parents and guardians play a vital role in determining students' attitude towards a subject.

HO: There is no significant difference in chemistry preparedness in terms of attitude towards chemistry, study skills and exam preparedness between low and high achievers.

In this survey, achievement was determined using the students' score in end term one chemistry tests.

Table 7 and Table 8 give the results of the t-tests on the basis of achievement.

Table 7.

\begin{tabular}{|c|c|c|c|c|c|}
\hline \multicolumn{6}{|c|}{ Group Statistics } \\
\hline & $\begin{array}{l}\text { End-term one Chemistry } \\
\text { score }\end{array}$ & $\mathrm{N}$ & Mean & Std. Deviation & Std. Error Mean \\
\hline \multirow[t]{2}{*}{ Attitude towards chemistry } & 34 and below & 33 & 3.1671 & .66960 & .11656 \\
\hline & $65-79$ & 46 & 3.6957 & .39056 & .05758 \\
\hline \multirow[t]{2}{*}{ Study skills } & 34 and below & 33 & 2.7358 & .58180 & .10128 \\
\hline & $65-79$ & 46 & 3.3357 & .30370 & .04478 \\
\hline \multirow[t]{2}{*}{ Exam preparedness } & 34 and below & 33 & 2.8232 & .69026 & .12016 \\
\hline & $65-79$ & 46 & 3.6522 & .39996 & .05897 \\
\hline
\end{tabular}

\section{1. $\mathrm{T}$ Test}

Table 8.

\begin{tabular}{|c|c|c|c|c|c|c|c|c|c|c|}
\hline \multicolumn{11}{|c|}{ Independent Samples Test } \\
\hline & & \multicolumn{2}{|c|}{$\begin{array}{l}\text { Levene's Test for } \\
\text { Equality of } \\
\text { Variances }\end{array}$} & \multicolumn{7}{|c|}{ t-test for Equality of Means } \\
\hline & & \multirow[b]{2}{*}{$\mathrm{F}$} & \multirow[b]{2}{*}{ Sig. } & \multirow[b]{2}{*}{$\mathrm{t}$} & \multirow[b]{2}{*}{$\mathrm{df}$} & \multirow[b]{2}{*}{$\begin{array}{l}\text { Sig. (2- } \\
\text { tailed) }\end{array}$} & \multirow[b]{2}{*}{$\begin{array}{c}\text { Mean } \\
\text { Difference }\end{array}$} & \multirow[b]{2}{*}{$\begin{array}{l}\text { Std. Error } \\
\text { Difference }\end{array}$} & \multicolumn{2}{|c|}{$\begin{array}{l}\text { 95\% Confidence Interval } \\
\text { of the Difference }\end{array}$} \\
\hline & & & & & & & & & Lower & Upper \\
\hline \multirow{2}{*}{$\begin{array}{l}\text { Attitude towards } \\
\text { chemistry }\end{array}$} & $\begin{array}{c}\text { Equal } \\
\text { variances } \\
\text { assumed }\end{array}$ & 16.410 & .000 & $\begin{array}{c}- \\
4.414\end{array}$ & 77 & .000 & -.52853 & .11973 & -.76695 & -.29010 \\
\hline & $\begin{array}{c}\text { Equal } \\
\text { variances not } \\
\text { assumed }\end{array}$ & & & $\begin{array}{c}- \\
4.065\end{array}$ & 47.514 & . .000 & -.52853 & .13001 & -.79000 & -.26705 \\
\hline \multirow{2}{*}{ Study skills } & $\begin{array}{c}\text { Equal } \\
\text { variances } \\
\text { assumed }\end{array}$ & 16.336 & .000 & $\begin{array}{c}- \\
5.962\end{array}$ & 77 & .000 & -.59997 & .10063 & -.80035 & -.39959 \\
\hline & $\begin{array}{c}\text { Equal } \\
\text { variances not } \\
\text { assumed }\end{array}$ & & & $5 . \overline{418}$ & 44.524 & .000 & -.59997 & .11074 & -.82307 & -.37687 \\
\hline \multirow{2}{*}{$\begin{array}{l}\text { Exam } \\
\text { preparedness }\end{array}$} & $\begin{array}{c}\text { Equal } \\
\text { variances } \\
\text { assumed }\end{array}$ & 8.527 & .005 & $\begin{array}{c}- \\
6.730\end{array}$ & 77 & .000 & -.82894 & .12317 & -1.07420 & -.58368 \\
\hline & $\begin{array}{c}\text { Equal } \\
\text { variances not } \\
\text { assumed }\end{array}$ & & & $6 . \overline{193}$ & 47.320 & .000 & -.82894 & .13385 & -1.09816 & -.55972 \\
\hline
\end{tabular}


The $\mathrm{p}$ values for the Lavene's test for homogeneity (Table 8) equal to .000 which is less than .05, hence, the null hypothesis 'there is homogeneity of variances' is rejected. The sig values for the dimensions in question are $\mathrm{P}=.000$ for attitude towards chemistry, $\mathrm{P}=.000$ for study skills and $\mathrm{P}=.000$ for exam preparedness. The null hypothesis 'there is no significant difference in chemistry preparedness in terms of attitude towards chemistry, study skills and exam preparedness between low and high achievers' is rejected. This means that the high achievers have different levels of preparedness for chemistry from the low achievers.

Table 7, suggests that the means for higher achievers are higher than for low achievers in the three dimensions. Higher achievers have more positive attitude towards chemistry $(\mu=3.6957)$ interpreting to high rating while the low achievers have positive attitude that rates average $(\mu=3.1641)$. Higher achievers recorded to practice better study skills as evidenced by average mean rating of $(\mu=3.3357)$ than low achievers $(\mu=2.7358)$. Similarly, higher achievers exhibit higher exam preparedness as indicated by the high mean rating of $(\mu=3.6522)$ than low achievers $(\mu=2.8232)$.

The findings are similar to those of other studies done in the recent past (Hofstein \& Naaman, 2011; Aydeniz \& Kaya, 2012). These studies indicate that students, who score low in science, have negative attitude towards it. The study associated the negative attitude in low performers with low self-esteem and lack of self efficacy.

HO: Attitude towards chemistry, study skills, and exam preparedness as aspects of chemistry preparedness are not correlated.

The Pearson product moment correlation coefficient was determined to measure the degree of relationship between variables. Table 9 gives information on levels of relationship between attitude towards chemistry, study skills and exam preparedness as measures of preparedness in chemistry.

Table 9.

\begin{tabular}{|c|c|c|c|c|}
\hline \multicolumn{5}{|c|}{ Correlations } \\
\hline & & $\begin{array}{c}\text { ATTITUDE TOWARDS } \\
\text { CHEMISTRY }\end{array}$ & STUDYSKILLS & EXAM PREPAREDNESS \\
\hline \multirow{3}{*}{$\begin{array}{c}\text { ATTITUDE } \\
\text { TOWARDS } \\
\text { CHEMISTRY }\end{array}$} & Pearson Correlation & 1 & $.596^{* *}$ & $.526^{* * \pi}$ \\
\hline & Sig. (2-tailed) & & .000 & .000 \\
\hline & $\mathrm{N}$ & 211 & 211 & 211 \\
\hline \multirow{3}{*}{ STUDYSKILLS } & Pearson Correlation & $.596^{* *}$ & 1 & $.740^{* *}$ \\
\hline & Sig. (2-tailed) & .000 & & .000 \\
\hline & $\mathrm{N}$ & 211 & 211 & 211 \\
\hline \multirow{3}{*}{$\begin{array}{c}\text { EXAM } \\
\text { PREPAREDNESS }\end{array}$} & Pearson Correlation & $.526^{* *}$ & $.740^{* *}$ & 1 \\
\hline & Sig. (2-tailed) & .000 & .000 & \\
\hline & $\mathrm{N}$ & 211 & 211 & 211 \\
\hline
\end{tabular}

All the P-values are less than .005 (sig=.000) implying that the null hypothesis 'attitude towards chemistry, study skills, and exam preparedness as aspects of chemistry preparedness are not correlated' ought to be rejected. There is a moderate positive relationship between attitude towards chemistry and study skills (Pearson $\mathrm{r}=.596$ ). Similarly, attitude towards chemistry has a moderately positive relationship with exam preparedness (Pearson $\mathrm{r}=.526)$. The relationship between study skills and exam preparedness is strongly positive (.740). The way a student studies determines how prepared the student is towards exams, so that the more and better the study skills, the more the student is prepared to tackle exams.

\section{Conclusions and Recommendations}

This study intended to test if there was significant difference in chemistry preparedness in terms of attitude towards chemistry, study skills and exam preparedness between boys and girls, between boarders and day scholars and between low and high achievers. It also aimed at testing the relationship between the students' attitude, study skills and exam preparedness in chemistry. Two hundred and eleven (211) subjects participated. A questionnaire was designed to measure preparedness in chemistry in relation to attitude towards chemistry, study skills, and exam preparedness. To address the hypotheses, frequency distributions and other descriptive statistics including means, standard deviations and percentages were used. Independent sample t-tests were performed to address the first and the second hypotheses to determine whether differences between variables existed. The findings also inform that preparedness in chemistry in terms of attitude towards chemistry, study skills, and exam preparedness is the same in both boys and girls but boys lagged slightly below girls in attitude towards chemistry. There was no significant difference in chemistry preparedness between genders in relation to these variables. Borders and day scholars have similar preparedness in chemistry in terms of attitude, study skills and exam preparedness. The results further show that day scholars have a slightly higher preparedness in chemistry than the boarders. Higher achievers have more positive attitude towards chemistry, better study skills and higher exam preparedness. The three variables are correlated.

Being ready to learn is an essential ingredient. It can help students develop better learning habits and strengthen their study skills, apply learning strategies to enhance academic outcomes, monitor their learning process, and evaluate their academic concerns. This, therefore, suggests that teachers should familiarize with the factors that influencing the learner's ability to prepare to learn and the strategies they can use to identify and promote selfregulated learning in their classrooms. In addition to selfregulation, motivation can have a long-lasting impact on students' academic outcomes.

\subsection{Recommendations for Further Studies}

1. A replica of the study can be carried out in schools in different area for comparative purposes. For example to compare rural and urban, boys' and girls' in single sex schools. 
2. A study can be carried to determine causes of poor performance if students have positive attitude towards a subject.

3. A study on the relationship between job aspirations and attitude towards chemistry can also be done.

\section{References}

[1] Aiken, L. R., \& Aiken, D. R. (1969). Recent research on attitudes concerning science. Science Education, 53, 295-305.

[2] Andreassen, R. \& Braten, I. (2011). Implementation and effects of explicit reading comprehension instruction in fifth-grade classrooms. Learning and Instruction, 21, 520-537.

[3] Al-Hilawani, Y.A.and Sartawi, A. A. (1997), "Study Skills and Habits of Female University Students," College Student Journal, $31,537-544$.

[4] Allgood, W.P., Risko, V.J., Alvarez, M.C. and Fairbanks, M.M. (2000), "Factors that Influence Study," In R.F. Flippo and D.C. Caverly (Eds.).Handbook of College Reading and Study Research. Mahwah, NJ: Lawrence Erlbaum Associates.

[5] Aydeniz, M. \& Kaya, E. (2012). Factors impacting Turkish students' attitudes towards science and their academic performance in science. Turkish Science Education, 9 (2), 25-48.

[6] Azubuike, O.C. (2011). Influential Factors Affecting the Attitude of Students Towards Vocational/Technical Subjects in Secondary Schools South Eastern Nigeria. Educational and Social Research, 1 (1), 49-56.

[7] Boekaerts, M. \& Corno, L. (2005). Self-regulation in the classroom: A perspective on assessment and intervention. Applied Psychology: An International Review, 54 (2), 199-231.

[8] Butler, R. (1998). Determinants of help seeking: Relations between perceived reasons for classroom help-avoidance and helpseeking behaviors in an experimental context. Journal of Educational Psychology, 90, 630-643.

[9] Butler, D. L., \& Winne, P. H. (1995). Feedback and self-regulated learning: A theoretical synthesis. Review of Educational Research, 65, 245-281.

[10] Can, H.B. (2012). Students' attitudes towards school chemistry: the effect of interaction between gender and grade level. AsiaPacific Forum on Science Learning and Teaching, 13 (1), 1-16.

[11] Carver, C. S., \& Scheier, M. F. (1990). Origins and functions of positive and negative affect: A control-process view. Psychological Review, 97, 19-35.

[12] Cheung, D. (2007). Students' attitude towards chemistry lessons: the interactive effect between grade level and gender. Res Sci Educ 2009 (39), 75-79.

[13] Cheung, D. (2009). Developing a scale to measure students'attitudes toward chemistry lessons. International Journal of Science Education, 31 (16), 2185-2203.

[14] Clarebout, G., Horz, H., \& Schnotz, W. (2010). The relations between self-regulation and the embedding of support in learning environments. Educational Technology Research and Development, 58 (5), 573-587.

[15] Cleary, T. J., \& Zimmerman, B. J. (2004). Self-regulation empowerment program: A school-based program to enhance selfregulated and self-motivated cycles of student learning. Psychology in the Schools, 41, 537-550.

[16] Corno, L. (1993). The Best-laid plans: Modern conceptions of volition and educational research. Educational Researcher, 22, 1422.

[17] De Bruin, A.B., Thiede, K.W., \& Camp, G. (2001). Generating keywords improves metacomprehension and self-regulation in elementary and middle school children. Journal of Experimental Child Psychology, 109 (3), 294-310.

[18] De Corte, E., Mason, L., Depaepe, F., \& Verschaffel, L. (2011). Self-regulation of mathematical knowledge and skills. In B. J. Zimmerman, \& D. H. Schunk (Eds.), Handbook of self-regulation of learning and performance (pp. 155-172). New York: Routledge.

[19] Dignath, C. \& Buttner, G. (2008). Components of fostering selfregulated learning among students. A meta-analysis on intervention studies at primary and secondary school level. Metacognition and Learning, 3, 231-264.

[20] Di Vesta,F.J. and Moreno, V. (1993), "Cognitive Control Functions of Study Activities: A Compensation Model," Contemporary Educational Psychology, 18 (1), 47-65.
[21] Elliot, L., Foster, S. and Stinson, M. (2002), "Student Study Habits using Notes from Speech-to-Text Support Service." Council of Exceptional Children, 69 (1), 25-40.

[22] Francis, L. J. \& Greer, J. E. (1999). Measuring attitude toward science among secondary school students: The affective domain. Research in Science \& Technological Education, 17 (2), 219-226.

[23] Glasman, L. R. \& Albarracín, D. (2006). Forming attitudes that predict future behavior: A meta-analysis of the attitude-behavior relation. Psychological Bulletin, 132 (5), 778-822.

[24] Graham, S., Harris, K. R., \& Mason, L. (2004). Improving the writing performance, knowledge, and self-efficacy of struggling young writers: The effects of self-regulated strategy development. Contemporary Educational Psychology, 30, 207-241. Harnishferger, K. K. (1995). The development of cognitive inhibition: Theories, definitions, research. In F. N.

[25] Dempster \& C. J. Brainerd (Eds.), Interference and Inhibition in Cognition (pp. 176-206). San Diego: Academic Press.

[26] Hofstein, A. \& Naaman, R.M. (2011). High school students' attitude toward and interest in learning chemistry. Educación química, 22 (2), 90-102.

[27] Hofstein, A., Ben-zvi, R., Samuel, D., \& Tamir, P. (1977) Attitudes of Israeli high-school students toward chemistry and physics: A comparative study. Science Education, 61 (2), 259-268.

[28] Hoover, J.J. (1989), “Study skills,” In E.A. Polloway. J.R. Patton, J.S. Payne, and R.A. Payne. Strategies for Teaching Learners with Special Needs (4th ed.). New York: Macmillan Publishing Company.

[29] Inzahuli, S.M., Role, E. \& Makewa, L. N. (2012). Gender Disparities in Self-concept, Attitude and Perception in Physics and Chemistry. Atlas Journal of Science Education 2 (1): 61-69 2012.

[30] Jones, C.H., Slate, J.R. and Kyle, A. (1992), "Study Skills of Teacher Education Students,” Teacher Education, 28 (1), 7-15.

[31] Kind, P. M., Jones, K., \& Barmby, P. (2007). Developing attitudes towards science measures. International Journal of Science Education, 29 (7), 871-893.

[32] King, A. (1992), "Comparison of Self-Questioning, Summarizing, and Note Taking Review as Strategies for Learning from Lectures," American Educational Research Journal, 29, 303-323

[33] Koballa, T. R. (1988). Attitude and related concepts in science education. Science Education, 72, 115-126.

[34] Koballa, T. R., \& Crawley, F. E. (1985). The influence of attitude on science teaching and learning. School Science and Mathematics, 85 (3), 222-232.

[35] Kolovelonis, A., Goudas, M., \& Dermitzaki, I. (2011). The effect of different goals and self-recording on self-regulation of learning a motor skill in a physical education setting. Learning and Instruction, 21 (3), 355-364.

[36] Kuhl, J. (1998) Volitional mediators of cognition-behavior consistency: self-regulatory processes and action versus state orientation. In J. Kuhl and J. Beckman (eds) Action Control: From Cognition to Behavior (pp. 101-128). New York: Springer.

[37] Labuhn, A.S., Zimmerman, B.J., \& Hasselhorn, M. (2010). Enhancing students' self-regulation and mathematics performance: The influence of feedback and self-evaluative standards Metacognition and Learning, 5 (2), 173-194.

[38] Nyamba, S.Y. \& Mwajombe, K.K. (2012). Students' preferences on science subject: does this affect their performance?: a case study of Udzungwa Secondary School, Kilolo, Iringo, Tanzania. International Journal of Science and Technology, 20(8), 556-560.

[39] Osborne, J., \& Collins, S. (2000). Pupils' and parents' views of the school science curriculum. London: King's College London.

[40] Osborne, J., Simon, S., \& Collins, S. (2003). Attitudes toward science: A review of the literature and its implications. International Journal of Science Education, 25 (9), 1049-1079.

[41] Paris, S. G. and Winograd, P. (2001), "The Role of Self-Regulated Learning in Contextual Teaching: Principles and Practices for Teacher Preparation,” U.S. Department of Education Project Preparing Teachers to Use Contextual Teaching and Learning Strategies To Improve Student Success In and Beyond School, (accessed August 17, 2014), available at http://www.ciera.org/library/archive/2001-04/0104parwin.htm.

[42] Quinn, G. P. \& Keogh M. J. (2002). Experimental design and data analysis for biologists. NY, USA: Cambridge University Press.

[43] Ryan, A. M., Pintrich, P. R., \& Midgley, C. (2001). Avoding seeking help in the classroom: Who and why? Educational Psychology Review, 13, 93-114. 
[44] Satta, K. \& Tzougraki, C. (2004). Attitude towards chemistry among $11^{\text {th }}$ grade students in high schools in Greece. Science Education, 88 (1), 525-547.

[45] Schibeci, R. A. (1984). Attitudes to science: An update. Studies in Science Education, 11, 26-59.

[46] Schunk, D. \& Zimmerman, B. (2007). Influencing children's selfefficacy and self-regulation of reading and writing through modeling. Reading \& Writing Quarterly, 23 (1), 7-25.

[47] Schraw, G., \& Moshman, D. (1995). Metacognitive theories. Educational Psychology Review, 7, 351-371.

[48] Shrigley, R. L. (1990). Attitude and behavior are correlates. Journal of Research in Science Teaching, 27, 97-113.

[49] Simpson, R. D., \& Oliver, J. S. (1990). A summary of the major influences on attitude toward and achievement in science among adolescent students. Science Education, 74, 1-18.

[50] Souvignier, E. \& Mokhlesgerami, J. (2006). Using self-regulation as a framework for implementing strategy instruction to foster reading comprehension. Learning and Instruction, 16, 57-71.

[51] Spall, K., Dickson, D., \& Boyes, E. (2004). Development of school students' constructions of biology and physics. International Journal of Science Education, 26 (7), 787-803.

[52] Stanley, B., Slate, J.R. and Jones, C.H. (1999), "Study behaviors of college preparatory and honors students in the ninth grade," The High School Journal, 82 (3), 165-171.

[53] Stoeger, H., \& Ziegler, A. (2011). Self-regulatory training through elementary-school students' homework completion. In B. J. Zimmerman, \& D. H. Schunk (Eds.), Handbook of self-regulation of learning and performance (pp. 87-101). New York: Routledge.

[54] Tonks, S. M., \& Taboada, A. (2011). Developing self-regulated readers through instruction for reading engagement. In B. J. Zimmerman, \& D. H. Schunk (Eds.), Handbook of self-regulation of learning and performance (pp. 173-186). New York: Routledge.
[55] VanMeter, P., Yokoi, L. and Pressley, M. (1994), "College Students' Theory of Note-Taking Derived from Their Perceptions of Note-Taking,” Journal of Educational Psychology, 86, 323-338.

[56] Weinburgh, M. (1995). Gender differences in student attitudes toward science: A meta-analysis of the literature from 1970 to 1991. Journal of Research in Science Teaching, 32, 387-398.

[57] Winne, P. H. (1995). Inherent details in self-regulated learning. Educational Psychologist, 30, 173-188.

[58] Winne, P. H., \& Hadwin, A. F. (1998) Studying as self-regulated learning. In D. J. Hacker \& J. Dunlosky (Eds.), Metacognition in educational theory and practice, The educational psychology series. Mahwah, NJ: Erlbaum.

[59] Wolters, C. A. (2003). Regulation of motivation: Evaluating an underemphasized aspect of self-regulated learning. Educational Psychologist, 38, 189-205.

[60] Wolters, C. A., \& Pintrich, P. R. (1998). Contextual differences in student motivation and self-regulated learning in mathematics, English, and social studies classrooms. Instructional Science, 26, 27-47.

[61] Wood, E., Willoughby, T., McDermott, C., Motz, M., Kaspar, V. and Ducharme, M.J. (1999), "Developmental differences in study behavior," Journal of Educational Psychology, 91, 527-536.

[62] Yager, R. E., \& Yager, S. O. (1985). Changes in perceptions of science for third, seventh, and eleventh grade students. Journal of Research in Science Teaching, 22 (4), 347-358.

[63] Zimmerman, B., \& Risemberg, R. (1994). Becoming a selfregulated writer: A social cognitive perspective. Contemporary Educational Psychology, 22, 73-101.

[64] Zimmerman, B. J. (2004). Sociocultural influence and students' development of academic self-regulation: A social-cognitive perspective. In D. M. McInerney \& S. Van Etten (Eds.), Big theories revised (pp. 139-164). Greenwhich, CT: Information Age. 